Article

\title{
Choice, Inclusion, and Access to Information: Understanding Female Farmers' Participation in Kyrgyzstan's Water-User Associations
}

\author{
Rebecca Nixon ${ }^{1, *}$ and Francis Owusu ${ }^{2}$ \\ 1 Department of Forestry and Natural Resources, Purdue University, West Lafayette, IN 47907, USA \\ 2 Department of Community and Regional Planning, Iowa State University, Ames, IA 50011, USA; \\ fowusu@iastate.edu \\ * Correspondence: nixon17@purdue.edu; Tel.: +1-765-496-3649 \\ Academic Editor: Jessica Ulrich-Schad \\ Received: 30 October 2017; Accepted: 12 December 2017; Published: 15 December 2017
}

\begin{abstract}
Participatory processes have been widely promoted within the field of natural resource management as a method of supporting efficient resource use and, within these processes, much emphasis has been placed on gendered participation. In Kyrgyzstan, participation in irrigation management is organized through water-user associations (WUAs), a decentralized system of management commonly prescribed to increase equity and efficiency in water distribution. Women in Kyrgyzstan are active in irrigated agriculture particularly in light of changing demographics due to labor migration, yet they make up a small percentage of the members and leaders in these WUAs. This study draws upon interviews with WUA officials, village leaders, and female farmers in five communities in southern Kyrgyzstan to examine the determinants of female farmers' participation in WUAs. We argue that female farmers are strategic in how they choose to irrigate outside of the WUAs as users or participate in WUAs as members or leaders, however their gender, age, and class limits their access to information about WUAs and inclusion in WUA activities. These findings suggest the need to reassess participatory processes in WUAs in order to increase female farmers' inclusion in WUAs and demonstrates the complexity of gendered participation in natural resource management.
\end{abstract}

Keywords: natural-resource management; participation; gender; water-user associations

\section{Introduction}

The decentralization of water management, often in the form of water-user associations (WUAs), has often been prescribed to promote a more equitable and efficient water distribution while empowering water users as decision makers [1,2]. Although research on WUAs' influences on efficiency, cost, and equity have revealed varied results, WUAs are often promoted for their potential to decrease water-management costs, improve incentive for farmers' productive use of water, and promote timely problem-solving [3]. Among the many countries that have implemented WUAs is the Central Asian nation of Kyrgyzstan. There, WUAs were first established in 1995 to support the operation and maintenance of the irrigation system in the newly independent nation following the collapse of the Soviet Union. These WUAs allow for decentralized decision making and farmer participation, and as women are known to be key stakeholders in both domestic and agricultural water use [2], it follows that their participation is key in WUA functions and sustainable water use.

Many researchers have studied women's participation in WUAs, focusing specifically on the formal and informal barriers that limit their involvement despite being key stakeholders in water use. These studies have shown that WUA membership requirements that favor male positions in the community, such as land ownership or head-of-household status, systematically exclude women from 
participation in these organizations [4,5]. In addition, social norms that dictate male dominance in public spheres limit women's ability to lead, attend, or vocally contribute in community meetings $[5,6]$. Thus, in places where participation would be outside of gendered norms, a female farmer may choose not to participate in WUAs in order to maintain her social status in the community [7]. Women's time-poverty due to household responsibilities also limits their ability to attend community meetings where knowledge transfer and decision making occur [4,5,8]. Additionally, when women do participate in community management, it has been shown that their opinions and values may not be given much weight in the decision-making process [9].

While much emphasis has been placed on gendered exclusions, the role of other socioeconomic characteristics, especially how they intersect with gender to shape participation in natural resource management, has not received much attention in the literature. As Sultana (2009) illustrates, class, ethnicity, and educational level influence women's access to water [10]. Hierarchies based on age, race, geographical context, and religion have also been shown to influence participation $[8,11,12]$. As a result of these exclusions, initiatives intended to promote community decision-making processes have been criticized for supporting the status quo of gendered inequality, enabling existing power structures and exacerbating exclusions $[4,10,13,14]$.

Participation and access to information are seen as a key elements of empowerment [15] but it has been demonstrated that there are multiple types of participation. Thus, it cannot be assumed that all types promote empowerment $[13,16,17]$. In natural resource management, specifically, Agrawal (2001) presents six forms of participation ranging from nominal to interactive (empowering) participation [18]. Furthermore, Cleaver (1999) argues that when access to an essential resource is scarce or difficult to obtain, participation becomes a necessity rather than an expression of agency or choice [19].

However, water access is not solely dependent on participation. Rather, when faced with exclusions, Zwarteveen and Neupane (1996) demonstrate that women can effectively use informal means to access water and resolve conflicts [6]. Thus, when female farmers are able to obtain water outside of WUAs through informal means, they could view their participation in WUAs as an unnecessary and time-consuming activity—costs that contribute to their choice not to participate. However, these informal ways of obtaining irrigation water are typically less secure than the formal means of the WUA. This non-participation can also contribute to low financial viability of the WUA if users are not paying fees and allows unregulated and potentially inefficient water use to continue $[9,14]$. As these water resources are forecasted to become increasingly stressed [2], promoting efficient management and increased inclusion is vital to sustainable water use and water security. The existing critiques of participatory development and WUAs juxtaposed with the need to promote sustainable water management prompts a consideration of the factors that influence female farmers' participation within WUAs. This paper explores female farmers' participation in WUAs to assess the ways in which they are included or excluded from the participatory processes within WUAs in southern Kyrgyzstan. Some research has demonstrated women's membership and leadership in WUAs in Central Asia [20,21] but not much work has been done on women who irrigate outside of the WUAs. In addition, there is little work done in Central Asia that assesses the determinants of female farmers' participation in WUAs. This study adds to our understanding of the factors that influence female farmers' participation in WUAs in Kyrgyzstan. We argue that exclusion, limited access to information, and choice limit female farmers' membership in WUAs. Furthermore, the structure of WUAs offers disproportionate benefits to male farmers, causing female farmers to choose to irrigate their farms outside WUAs.

The next section of the paper describes the agricultural context and background of WUAs in Kyrgyzstan. This is followed by a discussion of the data-collection methods. The results of the study are then presented. Finally, we discuss how our results reveal the ways that exclusion/inclusion, access to information, and choice determine female farmers' participation in WUAs. 


\section{Water-User Associations and Agriculture in Kyrgyzstan}

The implementation of WUAs in Kyrgyzstan is a part of the wider establishment of similar participatory associations around the world in response to states' failures in irrigation management. It is argued that participation decreases costs for governments as farmers take on responsibilities, improves farmers' incentives to manage water productively, and increases efficiency through local management's quick response to problems or changes [3]. Neoliberal policies promoted by international donors increased the devolution and democratization of water governance [22] and sustainable development initiatives also encouraged user participation in natural-resource management [23]. Thus, irrigation-management transfer (IMT), often in the form of WUAs, has become an increasingly common prescription for addressing issues of infrastructure deterioration, allocation inefficiency, and economic infeasibility in water management.

However, because water management is embedded in social, political and cultural contexts and is not merely technological, the effectiveness of uniform IMT and WUA systems across diverse socio-political contexts has been questioned [24]. Just as contexts are diverse, so too are the needs and desires of the farmers within these contexts. Thus, it has been argued that the transfer of irrigation management requires not merely improved implementation, but a complete paradigm shift away from assumptions of farmer homogeneity [25].

In Central Asia, including in Kyrgyzstan, WUAs were established in the midst of the collapse of the Soviet Union and were a part of the land and water reforms backed by international donors in support of decentralization and privatization policies [26]. While they were implemented in the 1990s, these associations continue to vary in functionality and capacity. There are cases of improved irrigation timing and fee collection in Central Asia through WUAs, but the efficiency and financial sustainability of some of these associations have been questioned [20,27]. Problems that include farmers' inability or unwillingness to pay water fees, infrastructure deterioration, and lack of institutional and technical support influence the effective functioning of these institutions $[20,27,28]$. Indeed, farmers' reluctance to participate in IMT has been documented throughout Asia [25]. Furthermore, it has been argued that participatory management in Uzbekistan and Kazakhstan has been largely influenced by local sociopolitical contexts and thus has not met the standards of IMT as set by the international community [24]; and that the legacy of centralized Soviet policies is not conducive to the participatory process [28,29].

In Kyrgyzstan, in the years following independence from the Soviet Union and as a part of the transition from communal ownership of resources to private ownership, the government enacted various policies to organize and regulate on-farm irrigation systems. In 1994 the government issued "Measures to Maintain and Finance Public Irrigation Infrastructure" which gave the responsibilities of on-farm irrigation to existing village councils. In 1995, four years after independence, the parliament passed the Water Code, marking the implementation of irrigation services fees (ISFs) in the Kyrgyz Republic as well as the first resolution to establish WUAs with support from the World Bank and Asian Development Bank (ADB) [27]. This resolution was amended in 1997 with several changes to address water conflicts, fees, and the rights of farmers [30]. In 2002, the WUA law was amended again to become the present law that identifies WUAs as non-commercial organizations and establishes their current roles and functions. In contrast to the previous laws, the 2002 Water Law promotes the participation of farmers in decision-making processes, transparency in finances, and open access to information. It outlines the members' rights to participate in setting water fees, electing council members, and approving budgets and work plans [31]. In addition to the rights of members, it also outlines their responsibilities to pay ISFs in a timely manner and irrigate according to the WUA schedule [32]. While these policies do support farmers' participation, the Water Law does not explicitly address gender issues in water management and despite their role in agriculture, women's participation in WUAs in Kyrgyzstan is limited. It is difficult to measure gender disaggregated participation nationwide, but the Food and Agriculture Organization (FAO) (2016) estimated that in 2009, only $18 \%$ of WUA members were women [32]. As of 2011, there were 478 registered WUAs throughout the country, 
covering about $72 \%$ of the country's irrigated land [33]. As of 2009, there were over 166,000 members in WUAs [20].

WUAs in Kyrgyzstan are faced with infrastructural and economic inefficiencies as well as environmental pressures. First, the redistribution of land after the collapse of the Soviet Union drastically transformed the agricultural landscape, and the irrigation system that once served centralized kolkhoz and sovkhoz farms (collective and state-owned farms in the Soviet Union) is now utilized to distribute water to many smallholder farmers. Specifically, it is estimated that Kyrgyzstan's irrigation distribution is operating at $55 \%$ efficiency due to the poor condition of the canals [34]. Second, ISFs do not cover WUA costs [27] and while there has been reported improvement in ISF collection rates, it is still low throughout the country with many in-kind payments being used to pay ISFs [27]. Consequently, many WUAs are indebted to the RayVodKhoz (District Water Administration) and rely on the support of the local government to sustain their organization. Third, according to Intergovernmental Panel on Climate Change, Kyrgyzstan's winter precipitation is projected to increase while summer precipitation is expected to decrease, creating drier conditions during the growing season and a higher demand for water [35]. For Kyrgyzstan, this means that water availability will become more variable, increasing the need for efficiency in distribution and use and requiring equitable participation to ensure all farmers have access to this resource. This will also be necessary for regional sustainability, as demand from countries downstream from Kyrgyzstan will continue even as supply decreases.

In the midst of WUA inefficiencies and environmental change, access to irrigation water is vital to the livelihoods of the vast majority of farmers in Kyrgyzstan. Agriculture is the largest employer of both men and women in Kyrgyzstan and $80 \%$ of the cultivated land (1.02 million ha) relies on irrigation water [34]. Additionally, $50 \%$ of all employed women and $68 \%$ of all employed men work in agriculture and the share of women has increased over the past decade in part due to male employment opportunities in other sectors coupled with the migration of men out of rural areas $[32,35,36]$. Specifically, it is estimated that $20 \%$ of the Kyrgyz population is working abroad, predominantly in Russia and Kazakhstan. Young, male migrants make up a majority of this group: of the migrants to Russia, $65 \%$ of them are under 30 years old and $62 \%$ of those under 30 are male [37] and this does not include the many internal migrants who move to urban centers within the country. This out-migration of men leaves rural women with increasing responsibilities and opportunities in what were once male-dominated spheres such as agriculture and more specifically, in irrigation. It is within this context that this study sought to examine female farmers' participation in WUAs in southern Kyrgyzstan in order to answer the following questions: (1) Which female farmers have access to information about WUAs? (2) How do female farmers participate in WUAs (e.g., users, members, leaders)? and (3) What influences female farmers' access to information and participation?

\section{Methods}

Data collection for this research occurred between April and July of 2016 in five WUA service areas (each service area is a geographic unit under one WUA's management) throughout southern Kyrgyzstan. (Research was approved by Institutional Review Board, Office of Responsible Research, Iowa State University.) These service areas were chosen to capture participation across a diversity of hydrological contexts: three of the areas receive water from a reservoir within Kyrgyzstan, one irrigates from a river, and another from a reservoir in Tajikistan. Because WUAs in Kyrgyzstan can vary significantly in capacity and governance, sampling from five WUAs allowed us to capture trends of participation across WUAs. Purposive sampling was employed to identify respondents who were contacted through gatekeepers in the community. While using gatekeepers has been questioned due to the bias that they bring by excluding certain groups or individuals from participating, it is also seen as an effective way to develop connections with individuals [38] and in cross cultural research performed by an outsider, gatekeepers provide necessary connections and introductions to the community [39]. In order to avoid bias from within WUAs, gatekeepers connected to the 
associations were not used. Respondents included 49 female farmers, nine WUA staff, and two government officials in these districts (see Table 1). Semi-structured in-depth interview methods were employed in the data collection. This approach to data collection is known to promote flexibility in exploring participants' responses while maintaining the structure needed to address key questions and topics [38]. We enquired about participants' experiences and beliefs surrounding water management and WUAs from the governmental, WUA official, and female farmer perspectives. Questions also focused on family background and demographics, agricultural activities, water access, irrigation management, WUA information and knowledge, and participation in the WUA. All interviews were conducted in Kyrgyz. (As language is a fundamental tool of qualitative research, the translation process can be especially complex and problematic. Translators have a significant influence on the data as they interpret, clarify, disregard, filter, or miscommunicate language [39]. Furthermore, language is embedded in culture; therefore, words and phrases can lose their true meaning when translated into another language and translations can create inaccuracies and misunderstanding of meanings even when the literal translation is correct [39]. In this research, interviews were translated into English during the interview process by the research assistant. The recordings were later listened to and re-translated into English to check for accuracy. The English was then transcribed verbatim. These translation processes were conducted by the same research assistant and myself, creating a bias of her singular translation of the interview. However, my [Rebecca] basic knowledge of the Kyrgyz language allowed me confirm or question translations when necessary and she often consulted colleagues if there was confusion about a translation. This translation process was a part of the cross-cultural methodology in which both the researcher and research assistant sought to reduce cultural and linguistic barriers. For an in-depth discussion on cross-cultural research that informed our methods, see Liamputtong, 2010 [39].) Descriptive statistics were used to identify basic trends in participants' socioeconomic characteristics, land use and ownership, and WUA participation. Grounded theory was then used to report patterns and topics in the qualitative data based on themes that emerged from the data by coding, sorting, and interpreting the coded data [38].

Table 1. Interviews Conducted.

\begin{tabular}{|c|c|c|c|c|c|c|}
\hline & Total & Service Area 1 & Service Area 2 & Service Area 3 & Service Area 4 & Service Area 5 \\
\hline Male officials & 9 & $\begin{array}{l}2 \text { (WUA chief } \\
\text { accountant, city } \\
\text { quarter leader) }\end{array}$ & $\begin{array}{l}2 \text { (WUA director, } \\
\text { village head) }\end{array}$ & $\begin{array}{l}1 \text { (WUA } \\
\text { director) }\end{array}$ & $\begin{array}{c}3 \text { (WUA director, } \\
\text { RayVodKhoz } \\
\text { director, accountant) }\end{array}$ & $\begin{array}{c}1 \text { (WUA } \\
\text { hydro technician) }\end{array}$ \\
\hline Female officials & 2 & 1 (WUA director) & 0 & $\begin{array}{c}1 \text { (WUA council } \\
\text { member) }\end{array}$ & 0 & 0 \\
\hline Female farmers & 49 & 4 & 13 & 18 & 3 & 11 \\
\hline
\end{tabular}

\section{Results}

As expected, the majority of the respondents were classified as users, defined as farmers who utilize irrigation water but do not participate in decision making and management in the WUAs. For the purpose of this study, WUA members were self-identified members who pay ISFs, attend WUA meetings, and are aware of WUA roles and regulations in the community. Because WUA membership is based on household, we relied on self-reported data to identify individual membership rather than a WUA roster. A leader is a respondent who holds an official position in the WUA. Non- participants are respondents who did not use irrigation water (see Table 2).

The average age of the respondent was 46 years old. Age of respondents was weighted towards older farmers largely due to the cultural respect for elders as it was usually expected that the interview took place with the oldest female in the household. Younger women were usually less willing, or had less available time to participate in the interview. The average household size of respondents was 5.7 persons, nearly reflective of the regional average of 5.3 [36]. The range of total land owned was from 0.2 ha to 2.15 ha and average land owned by respondents was 0.95 ha, less than the regional average of 1.7 ha [33]. The below-average size of land owned by our respondents may suggest that 
poorer segments of the communities with fewer resources and less land are less likely to participate in a WUA or afford ISFs. However, because the respondent's average land size is lower than the region's average, our data does not fully represent the spectrum of wealth in the community and female farmers' experiences in WUAs. This bias should be taken into consideration in the interpretation of the data.

Table 2. Selected demographics of female respondents.

\begin{tabular}{cccccccc}
\hline \multicolumn{7}{c}{ Household Status } \\
\hline & Total & $\begin{array}{c}\text { De Jure } \\
\text { HH }\end{array}$ & $\begin{array}{c}\text { De Facto } \\
\text { HH }\end{array}$ & $\begin{array}{c}\text { Household } \\
\text { Member }\end{array}$ & $\begin{array}{c}\text { Average } \\
\text { Age }\end{array}$ & $\begin{array}{c}\text { Average Household } \\
\text { Land Ownership (ha) }\end{array}$ & $\begin{array}{c}\text { Average Number } \\
\text { in Household }\end{array}$ \\
\hline WUA leaders & 2 & 1 & 0 & 1 & 58 & 3.15 & 5 \\
WUA members & 9 & 1 & 1 & 7 & 52 & 1.3 & 6 \\
Users & 35 & 8 & 3 & 24 & 45 & 0.83 & 5.7 \\
Non-users & 5 & 0 & 0 & 5 & 33 & 0.42 & 5.2 \\
All respondents & 51 & 10 & 4 & 37 & 46 & 0.95 & 5.7 \\
\hline
\end{tabular}

For the purposes of this research, de facto household heads (HHs) are female heads of households where the male head is absent or otherwise unable to act as $\mathrm{HH}$ for the majority of the irrigation period. De jure HHs refers to widows or unmarried, divorced or separated women who are HH. Of the respondents, $20 \%$ were classified as de jure $\mathrm{HH}$, largely due to the frequency of the labor migration of men, and $8 \%$ as de facto $\mathrm{HH}$ because their husbands were working in urban centers. These percentages are collectively reflective of the national estimate of $27 \%$ female $\mathrm{HH}$ [40].

Analysis of respondents' demographic data reveals interesting trends in participation by age and amount of land owned. On average, leaders were older than members, who were older on average than users. Similarly, leaders owned more land than members, who owned more land than users. The causes for these trends may vary and as this study did not employ random selection, it is not representative of the population. However, the influence of age and class (as indicated by land tenure and ability to afford ISFs) on WUA participation is supported by the interview data.

Drawing on existing literature (see especially $[8,10,18]$ ) and insights from this study, we present a system of participatory processes in natural-resource management (Figure 1). It shows that the socio-economic characteristics of female farmers' influence their access to information, inclusion in the organization, and the decision of whether or not to participate in WUA activities. These determinants of participation in turn impact the level at which an individual may participate in a WUA (i.e., as a user, member, or leader). These users, members, and leaders make up the natural-resource management process that should be equitable, efficient and empowering. This process is cyclical in nature; that is, a resource-management system characterized by inefficiency, inequity, and disempowerment can adversely affect access to information, opportunities for inclusion, and the choice to participate that female farmers ultimately make. Conversely, an efficient, equitable, and empowering process of natural-resource management promotes participation. Examining participation with this framework recognizes the complexity of socio-economic characteristics beyond gender that influence access to information and inclusion and, furthermore, that some users may choose not to participate. 


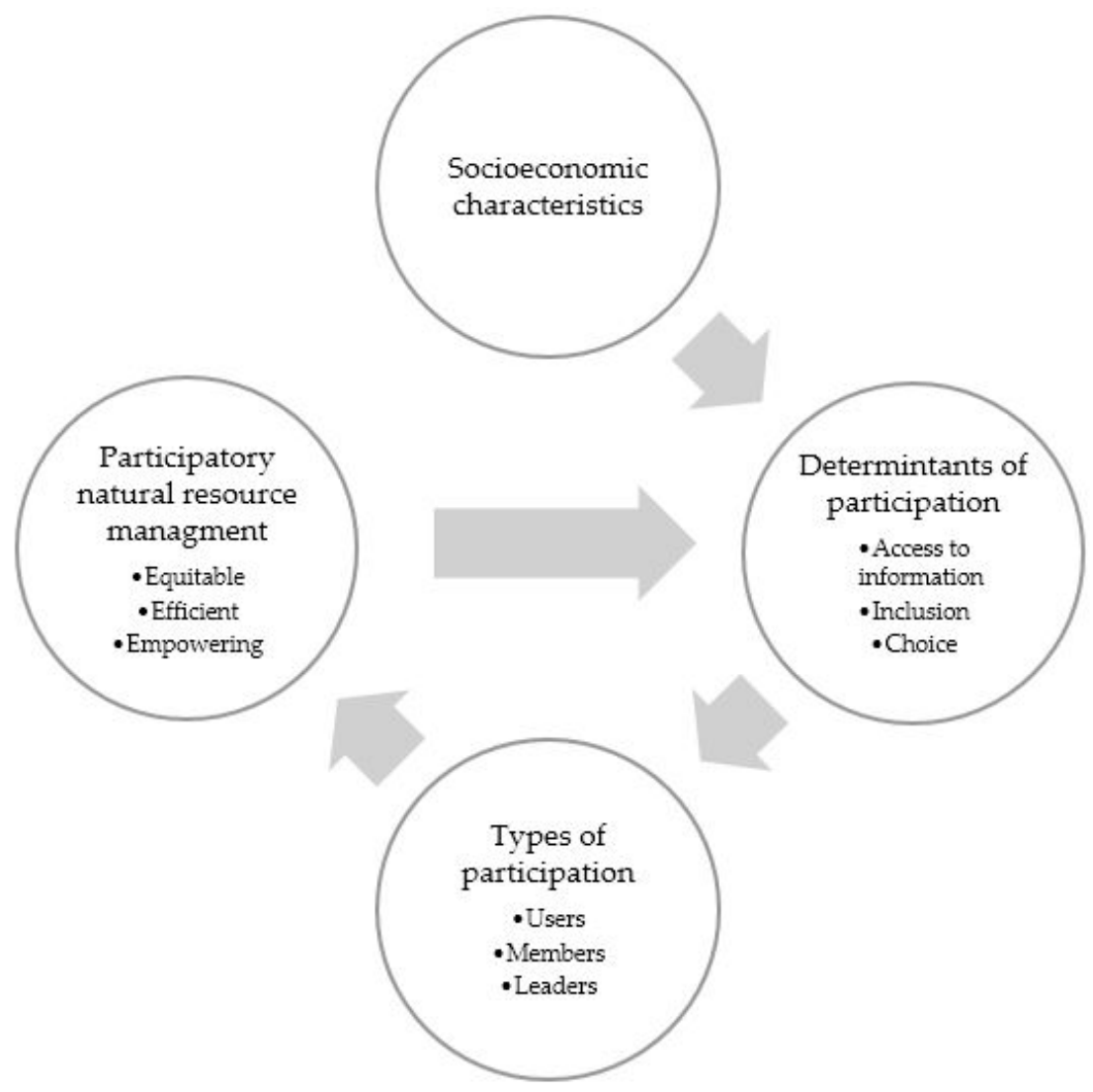

Figure 1. System of participatory processes in natural-resource management.

\section{Discussion}

\subsection{Socio-Economic Characteristics and WUA Membership}

This study supports the existing literature that has argued that participation in natural-resource management is not influenced by gender alone [8,10-12]; rather, that gender intersects with other socio-economic characteristics to shape determinants of participation. In the context of this study, class and age specifically intersected with gender to influence participation.

First, in this study, members were, on average, older than users, and the two leaders were older than the members. This trend is largely influenced by a cultural respect for elders coupled with divisions of labor that dictate young women's time poverty due to household responsibilities. Kyrgyzstan's traditional divisions of household labor leave young women with greater responsibilities within the home and, therefore, less time to attend meetings and fewer opportunities to invest in WUA membership. For example, respondents cited needing to stay home with their children as a reason for not attending WUA meetings. For young married women in particular, finding time for outside activities can be particularly difficult due to the expectation that they will begin to have children within the first year of marriage, and if married to the youngest son of a family, the responsibility to care for their in-laws. Specifically, the role of young married women as unpaid labor who replace the "worn out" mother-in-law is often seen as a normal and expected part of the family structure [41] (p. 29). In many cases, the bride is included as an equal member of the family; however, in others, especially in cases of bride-kidnapping (bride kidnapping (ala kachuu) is used to describe various situations ranging from a consensual elopement to a non-consensual kidnapping. Non-consensual bride kidnapping is officially a criminal offense but is popularly accepted as a traditional practice. Research conducted from 1999 to 2004 estimates that the number of ethnic Kyrgyz women married against their will as a result of bride kidnapping increased from $33 \%$ in 1999 to $45 \%$ in 2004 [41]), 
marriage is seen as a strategy "to increase the labor potential" in the family [41] (p. 30). In these situations, young women may be given the majority of the household work while the older women in the family are relieved of these responsibilities. One young user in this study observed that if women were attending WUA meetings, they were usually elderly women. Similarly, a member reported that she did not begin participating in the WUA until she was older; that is, until she was relieved of some of her household duties by her daughters and daughter-in-law and had more time and freedom to participate. These trends are exacerbated in rural, lower-class households with high labor needs and creates a context in which the older generation has time to invest outside the home in organizations such as a WUA while the younger women work at home.

In addition to having time available, older women have more respect in the community that grants them the ability to participate in a WUA. This results from the general expectation in Kyrgyzstan that elders should be respected and honored within the home and community. For women in particular, this may be rooted in traditional Kyrgyz culture that dictates that a woman has fulfilled her duty after her reproductive period or after the birth of a certain number of sons. This grants her a certain amount of freedom and allows older women to act outside of gender norms associated with younger women [41]. Specifically, this study showed that respect for age can be used to negotiate with other farmers and the myrab (the WUA staff member responsible for distributing irrigation water and collecting payments) when there is high competition for water, as one member reported:

If you want to sign up for your turn to get water the canal area is filled with cars and about 200 people go to get water. I tell people that I am an old eje (literally translated as older sister or aunt, this term is used in reference to any woman older than the speaker) and need water. I tell my myrab, "Please let me get water, I am an old eje."

Thus, in contrast to the young users, ejes' age allows them to act outside of the traditional gender norms. They are able to interact with both men and women and will often take an authoritative role in social situations.

Second, in addition to age, class, as defined as size of land owned and the ability to afford ISFs, seems to influence participation in a WUA. First, interviews with both farmers and officials showed that farmers who owned more land are more likely to participate in a WUA. This is reflected by the demographic data that suggested that WUA leaders tend to own the most land, followed by members, and with users owning the least amount of land on average. When asked about this trend, officials indicated that those with more land tend to benefit most from the WUA; they are less likely to secure sufficient water informally, thus are more likely to participate in a WUA. Second, farmers who report being unable to afford the ISFs required for participation in a WUA are likely to irrigate as users outside of WUA regulations. The average ISF in the research area is 7.54 tyin (1 Tyin $=0.01 \mathrm{KGS}$. At the time of writing, $1 \mathrm{KGS}=0.015 \mathrm{USD}$ ) per $\mathrm{m}^{3}$ of water, the highest in the country [33]. While it has been illustrated that these ISFs do not cover costs for the WUAs [27], users still spoke of the difficulty of affording ISFs. For one user, ISFs were an unaffordable expense due to medical issues. Others spoke of unemployment and the rising cost of ISFs as reasons they could not afford to pay the ISFs and consequently avoided membership in WUAs to evade paying the ISFs. Conversely, those with more land and potentially more wealth are likely to be able to afford to pay ISFs and be willing to invest the resources in irrigating their larger plots of land.

The affordability of ISFs is exacerbated by bribery, a practice found in other WUAs throughout the country [30]. As one official in this study put it, "people 'eat money' in the WUA" which makes it more difficult for those with limited finances to pay the unregulated ISFs. Conversely, multiple respondents claimed that if a farmer can pay bribes, they could get water without waiting for their scheduled time and without contributing labor to the WUA. This may motivate those who can afford to pay extra ISFs to irrigate as members so that they can benefit from this preferential treatment. But for farmers with limited financial resources, the need to pay ISFs may influence their decision to avoid working with the myrabs and instead secure water as a user. Indeed, Sehring (2005) reports that in some communities in Kyrgyzstan, "water theft is so common, that it can be described as a local institution itself as it 
presents a widely non-confronted rule of behavior" [27] (p. 33) which allows female farmers to irrigate as users without paying ISFs.

\subsection{Determinants of WUA Participation}

\subsubsection{Access to Information and WUA Participation}

Access to information has been shown to be key to participation [15] and allows farmers to be aware of both their rights and responsibilities as water users. Based on the interviews with female farmers, it appears that they have limited information about WUAs in general, including its existence, roles and functions. For instance, when asked about the management of their irrigation water, some of them attributed it to the village council, the RayVodKhoz, the governmental body over the WUA, or an ambiguous concept of 'the government'. This is reflective of the lack of knowledge of WUAs throughout the country [27,29]; however, the gendered division of labor in the Kyrgyz household also influences female farmers' access to information about WUAs. For women whose husbands or other male head of households irrigate, they may not know about the WUA because they do not need to know; irrigation is not their responsibility and, therefore, information about the WUA may be unnecessary. Nevertheless, our findings suggest that the assumption that women do not irrigate may not hold true in all circumstances, especially in situations where women are the de facto or de jure head of household. However, their status as household head does not always ensure their access to information about WUAs. For instance, a widowed respondent without a male representative in her community did not know who the myrab was, or the role of the WUA, despite being the head of the household and being responsible for irrigating her orchard. Other users confirmed that limited access to information is, indeed, a barrier to their participation in the WUA. One woman stated:

I heard there was [a meeting] last year. But I am mostly at home so I did not hear about it until after it happened so I could not attend. If we hear about them and they tell us we can go, I would go.

Thus, for these female farmers, they may have a desire to participate in a WUA but their lack of information about WUAs hinders their ability to actually participate. Officials in this study reported that information about WUAs was often communicated by word of mouth, and if female farmers do not have contacts with those who hold the information, they will remain unaware of the opportunities to participate. Thus, this spread of information often favors men with more mobility and interaction with those with the information.

\subsubsection{Inclusion/Exclusion and Participation}

Our findings suggest that in addition to limited access to information, female farmers' participation in WUAs was often impacted by the traditional segregation of gender roles, and the assumption about female farmers' limited involvement in, knowledge of, and ability to, irrigate. It was repeated by farmers and officials alike that irrigation was the responsibility of the men; however, this gendered division of labor has been challenged through the changing demographics in the region brought about by increasing labor migration, causing one respondent to report that her village had "a deficient of men." WUA officials in this study did acknowledge the demographic changes in their communities. However, officials often simultaneously expressed the need to include female farmers in the WUA with the idea that men hold the skill, knowledge, and physical ability needed for irrigation management and labor. Thus, this acknowledgment of changing demographics has not yet translated into institutional changes to increase the inclusion of female farmers in the WUA.

The gendered division of labor embedded in WUAs can be seen in both official WUA meetings and the traditional gathering of ashar. (A traditional practice of gathering community members for volunteer labor to build or maintain community structures such as mosques, schools, or water canals.) As one respondent said: 
Only men participate in ashar. We are not allowed to participate. I do not know why, but women do not participate. It is a shameful if we do.

Officially, the household representative in ashar does not have to be male, but according to social norms, women do not generally participate. This may be because cleaning the canal is a physically strenuous task and the assumption is that women lack the strength to clean the canal. This exclusion may not negatively affect women with male family members who can represent their family at the ashar; indeed, women may not want to take the time to participate in ashar. However, officials and farmers reported that participation in ashar can be a mandatory prerequisite for the myrab to give a farmer water. In other cases, officials will give preferential treatment to those who contributed to ashar. Thus, female farmers who are excluded from participating in ashar due to gendered exclusions and do not have a male household member to represent their family could be at a distinct disadvantage in securing water through the WUA.

In the WUA structure, the myrab is the main connection between the WUA and the farmers. However, our findings showed that all the myrabs in the study areas were male. The male dominance of this important role was identified as a barrier to female farmers' ability and willingness to work with WUAs and thus favors male participation. For instance, some female farmers expressed discomfort in interactions with male myrabs due to traditional segregation of gender roles. As one user said, "I do not work with the myrab. Maybe because I am a woman. I am too shy to talk to males." This barrier to communication with the male myrab could hinder female farmers' ability to ask for needed information about the WUA, negotiate irrigation schedules, or request the myrab's help in conflict resolution. These exclusions may cause particular difficulties for female farmers who are head of their household, as shown by this user's narrative:

My family situation is bad. I have five daughters ... Basically, people don't give water to the women without husbands, those whose husbands work as labor migrants in Russia. This is the main problem. Others can negotiate to get the water first. Families with men, they can oversee the distribution of water because they can close the water gates and get water for their own orchards. Because we are not participating, we are left behind by the men who monitor the water. We have to irrigate the land late at night and instead of sleeping, we get water.

Without sons to act as a representative in the WUA, she irrigated as a user, often irrigating at night to avoid the myrab and other farmers. Therefore, she relied on informal and less secure means of obtaining water without paying or consulting the myrab. This user also illustrates a common strategy female farmers in this study area used to secure water: irrigating at night. For some, this was a necessity to secure water. For others, this seemed to be the preferred choice to get water for their crops; they can avoid paying the ISFs and irrigate whenever there was water.

\subsubsection{Participation and Choice}

While farmers' level of participation in WUAs may be due to exclusions and access to information, sometimes, farmers' participation in WUAs is simply a matter of a choice by the farmers based on weighing the costs and benefits of participation. Each participation type-user, member, and leader-has specific benefits and costs that influence this choice. Some farmers may choose not to participate in a WUA due to the time required for membership. This may be especially the case for female heads of households who have more responsibilities, as reported by this user:

We, the women who have to endure the burden of being the breadwinners, we don't participate because we have other household activities that we have to complete. We do not have husbands, our children are young.

Women who are members of the household may also choose not to participate due to their expected responsibility for work within the household. As one user said, "I stay home with my 
children; there really is no time to participate in the WUA." Still others who work outside the home may choose not to attend WUA meetings, as captured by this user: "I am tired when I come home from work and sometimes the meetings occur when I am working. So I don't want to go [to the meetings]." For these users, the decision is driven by their inability or unwillingness to invest the time that is required of a WUA membership.

In addition to saving time as described above, users may choose not to participate in order to save money by avoiding ISF payments. As mentioned above, some users reported irrigating at night or simply opening the water gates whenever there is water, illustrating Agrawal (1997) and Zwarteveen and Meinzen-Dick's (2001) argument that non-participation that leads to unregulated use can decrease sustainability of the resource use $[9,14]$ :

If there is water at night, you should irrigate. We do not pay [for water]. We irrigate our land at night. When there is water, you can take it. When there is not water, but you need it, you just open the gate and change the direction of the water.

If users can get water access without WUA membership, they may see no benefit to spending their financial resources or time in participation, especially if they do not perceive any additional benefits to participation:

We discussed water issues [at the meeting] but the officials don't care. There is no one who can monitor the water to make sure things are working correctly. Officials say they are here to provide access to water. But they don't care. All they care about is money and we are the last thing they care about.

This perception that the WUA prioritizes money over the community has influenced this farmer's decision to irrigate without being a WUA member. She does not see the benefits to participating in the WUA, and so while she continues to pay ISFs, has stopped attending meetings. Perhaps, for some, this choice of non-participation is also an act of independence to convey their ability to maintain water access outside of the patriarchal system that does not benefit them as irrigators. As one user said, "No, I don't even want to go to the WUA! I will get water for myself, by myself." Instead of participating within a system that often excludes them as female farmers and disproportionately favors male users, these farmers choose to act outside of WUAs and irrigate as users.

While this study showed the majority of female farmers irrigating as users, this may be due to the below-average land plot size among the respondents. In contrast to these respondents who do not participate, some female farmers cite specific benefits they receive through their membership or leadership in WUAs. For instance, members and leaders report participating in WUAs due to the timeliness in delivery of water and access to relevant information:

I go [to the WUA meetings] to get adequate water. For example, in early spring, they organize meetings about canal cleaning. And they say if you clean the canal you will get water. Participation in those meetings is for our own benefit and to be informed about latest news, and to know the price [of water] ... how the schedule is designed, who the myrabs are, and how many myrabs will be working [in our area].

In addition to information, members also cited support from WUAs during water conflicts, as cited in this member's narrative:

Just this morning we had a conflict about water. My son went at our turn to irrigate but the neighbor did not allow him to get water because they said that they had gotten water for two hours from the myrab. It was also our turn, so the myrab must have told two families they had water at the same time. My mother said "Go talk to the myrab, they know the schedule." So we went to the myrab and he fixed the schedule and the problem was solved.

Thus, in comparison to users, members benefit from increased water security via formal access through the WUA that can ensure water delivery during conflict. That is not to say that membership 
guarantees conflict resolution, as many members reported unresolved conflict, but it does provide potential for conflict mitigation. WUA leaders, too, expressed that their involvement contributed to their water access and ensured that both they and their community received the irrigation water they relied on for their livelihoods:

Because of my farm, I am an active leader in the WUA. When there is no water, my crops will not grow so I need to support the work of the WUA. This is so they will deliver water on time. And when you get water on time, you will have a fertile harvest.

As mentioned above, these leaders do own more land than members and users on average. Thus, they could perceive greater benefits in formal access to irrigation water and choose not only to participate, but to invest further time in leadership of the WUA. This suggests that participation in WUAs could be higher in a sample that included female farmers with larger land plots.

In addition to individual benefits, however, the female leaders also commented that they choose to lead WUAs in order to increase water access for the community. As one leader said:

I can't sleep at night because I always think about water problems. I want to serve the people. The only thing I wish is that the lives of the farmers will get better. My obligation is to get the water to them. The better people's lives become, the happier I will be.

Indeed, this leader did create a program to support low-income water users in her community and expressed the desire to include more women in WUA leadership. Therefore, the decision to lead appears not to be merely for individual benefit, but also to improve water access for the entire community.

\section{Conclusions}

In Kyrgyzstan, WUAs have been tasked with the management of irrigation water in a context of high rural out-migration of men and increasing stress on the region's water resources. Furthermore, low financial viability and deteriorating infrastructure hinder efficiency and equity in water distribution. Female farmers' inclusion in WUAs is key to sustainable community management of resources in this context; however, this study has revealed female farmers' low membership in WUAs is influenced by lack of access to adequate information, choice, and gendered exclusions. Furthermore, female farmers' limited participation in WUAs reflects a structure of participation that favors male farmers' membership. As stated above, literature on participation in natural-resource management often emphasizes the benefits of the participation for all resource users in the management process, citing increased efficiency, empowerment, and equity. However, if participatory structures systematically favor men, these processes with be neither efficient, equitable, nor empowering as female farmers will continue to be both excluded and choose to irrigate as users rather than WUA members. Examples highlighted in this paper include participation arrangements that require time outside of the household and information networks dominated by male relationships. Thus, most female farmers often irrigate as users rather than members due to a deliberate choice made by the farmer, gendered exclusions, or lack of access to information. Rather than promoting female farmers' participation in existing WUAs, transforming the WUAs to eliminate these structural barriers will be key to increasing their inclusion. For instance, hiring female myrabs may promote communication among female farmers and providing written information so that they do not have to attend meetings could promote participation in ways that are beneficial to female farmers.

This study confirmed that participatory structures cannot be assumed to be inclusive; rather they are subject to the reinforcement of existing exclusions dictated by farmers' complex socio-economic characteristics and community dynamics. Gendered exclusions have been discussed and assessed in development initiatives since the 1970s; however, this study acknowledges that inclusion is not influenced by gender alone. Instead, promoting the full participation of female farmers in WUA activities would require a more nuanced discussion of identity and the ways in which 
the intersections of socio-economic characteristics influence participation. Specifically, this study illustrated that participation in WUAs was influenced not only by gender, but also by farmers' class and age. For example, an elderly female farmer with more land may have fewer barriers to membership than a younger female farmer. In this sense, our findings support the post-modernist view that women are not one homogenous group; it cannot be assumed that all female farmers experience the same advantages or disadvantages [42,43]. Furthermore, WUAs themselves exist within a complex socio-political context. Consequently, processes seeking to promote inclusion and equity should address participation in ways that acknowledge both the complexity of identity and context. These processes should not be implemented uniformly, but in context-specific approaches that acknowledge the heterogeneity of farmers' needs in order to promote their inclusion, choice to participate, and access to information to create a more efficient, equitable, and empowering participatory process.

Acknowledgments: This research was funded by the Global Funding for Graduate Students (Iowa State University's College of Agriculture and Life Sciences) and the Graduate Travel Award for International Study in Sustainable Livelihoods (Bob Butler and Lorna Michael Butler). This research would not have been possible without the work of Elita Bakirova, Almaz Zhaparov, and Meerim Baktybaeva.

Author Contributions: R.N. and F.O. designed the research, R.N. performed the field work, and R.N. and F.O. wrote the paper.

Conflicts of Interest: The authors declare no conflict of interest. The founding sponsors had no role in the design of the study; in the collection, analyses, or interpretation of data; in the writing of the manuscript; and in the decision to publish the results.

\section{References}

1. IWMI How to Establish a Water User Association? Practical Steps for Social Mobilizers. Available online: http:/ / www.iwmi.cgiar.org/regional-content/central_asia/pdf/wua_eng.pdf (accessed on 29 October 2017).

2. United Nations Development Programme. UNDP Human Development Report; 0-230-50058-7; Palgrave Macmillan: New York, NY, USA, 2006.

3. Groenfeldt, D.; Svendsen, M. Case Studies in Participatory Irrigation Management; 0-8213-4540-0; World Bank Institute: Washington, DC, USA, 2000.

4. Meinzen-Dick, R.; Zwarteveen, M. Gendered participation in water management: Issues and illustrations from Water Users' Associations in South Asia. Agric. Hum. Value 1998, 15, 337-345. [CrossRef]

5. Van Koppen, B. Gender in integrated water management: An analysis of variation. In Nature Resource Forum; Blackwell Publishing Ltd.: Hoboken, NJ, USA, 2001; Volume 25, pp. 299-312.

6. Zwarteveen, M.; Neupane, N. Free-Riders or Victims: Women's Nonparticipation in Irrigation Management in Nepal's Chhattis Mauja Irrigation Scheme; Research Report \#7; International Irrigation Management Institute: Colombo, Sri Lanka, 1996.

7. Zwarteveen, M.; Bennett, V. The connection between gender and water management. In Opposing Currents: The Politics of Water and Gender in Latin America; Bennett, V., Davila-Poblete, S., Rico, M., Eds.; University of Pittsburgh Press: Pittsburgh, PA, USA, 2005; pp. 13-29.

8. Das, P. Women's participation in community-level water governance in urban India: The gap between motivation and ability. World Dev. 2014, 64, 206-218. [CrossRef]

9. Agarwal, B. Environmental action, gender equity and women's participation. Dev. Chang. 1997, 28, 1-44. [CrossRef]

10. Sultana, F. Community and participation in water resource management: Gendering and naturing development debates from Bangladesh. Trans. Inst. Br. Geogr. 2009, 34, 346-363. [CrossRef]

11. Cleaver, F. Choice, complexity, and change: Gendered livelihoods and the management of water. Agric. Hum. Value 1998, 15, 293-299. [CrossRef]

12. Guijt, I.; Shah, M. The Myth of Community: Gender Issues in Participatory Development; 978-1853394218; Sage Publications: New Delhi, India, 1998.

13. Cornwall, A. Whose voices? Whose choices? Reflections on gender and participatory development. World Dev. 2003, 31, 1325-1342. [CrossRef] 
14. Zwarteveen, M.; Meinzen-Dick, R. Gender and property rights in the commons: Examples of water rights in South Asia. Agric. Hum. Value 2001, 18, 11-25. [CrossRef]

15. Narayan, D. Empowerment and Poverty Reduction: A Sourcebook; World Bank Publications: Washington, DC, USA, 2002.

16. Arnstein, S. A ladder of participation. J Am. Plann. Assoc. 1969, 35, 216-224.

17. White, S. Depoliticizing development: The uses and abuses of participation. Dev. Pract. 1996, 6, 6-15. [CrossRef]

18. Agarwal, B. Participatory exclusions, community forestry, and gender: An analysis for South Asia and a conceptual framework. World Dev. 2001, 29, 1623-1648. [CrossRef]

19. Cleaver, F. Paradoxes of participation: Questioning participatory approaches to development. J. Int. Dev. 1999, 11, 597. [CrossRef]

20. Abdullaev, I.; Yakubov, M. Assessing the gender performance of the water users associations of Central Asia: Case study from IWRM Ferghana Project. In Proceedings of the ICWC 39th Annual Water Conference, Almaty, Kazakhstan, 19-21 May 2004.

21. Stulina, G. Role of women in the irrigated agriculture sector in the Fergana Valley: Findings of field surveys. Irrig. Drain. 2015, 64, 491-500. [CrossRef]

22. Harris, L. Gender and emergent water governance: Comparative overview of neoliberalized natures and gender dimensions of privatization, devolution, and marketization. Gend Place Cult. 2009, 16, 387-408. [CrossRef]

23. Farolfi, S.; Hassan, R.; Perret, S. Water Governance for Sustainable Development: Approaches and Lessons from Developing and Transitional Countries; Quae: Versailles, France, 2006.

24. Zinzani, A. The reconfiguration of participatory irrigation management in water users associations: Evidence from Uzbekistan and Kazakhstan. Cahiers d'Asie Centrale 2015, 25, 133-153.

25. Mukherji, A.; Fuleki, B.; Shah, T.; Suhardiman, D.; Giordano, M.; Weligamage, P. Irrigation Reform in Asia: A Review of 108 Cases of Irrigation Management Transfer; Final Report to the Asian Development Bank; International Water Management Institute (IWMI): Columbo, Sri Lanka, 2009.

26. Ghazousni, W.; Molle, F.; Rap, E. Water User Associations in the NEN Region: IFAD Interventions and Overall Dynamics; IWMI: Columbo, Sri Lanka, 2012.

27. Sehring, J. Water User Associations in Kyrgyzstan; Discussion Paper; Zentrum für Internationale Entwicklungsund Umweltforschung (ZEU): Gießen, Germany, 2005; Volume 25.

28. Nizamedinkhodjayeva, N. Rural livelihoods and irrigation management transfer: Case-study of three countries in the Ferghana Valley of Central Asia. JAIS 2007, 42, 41-60.

29. Wegerich, K. Water User Associations in Uzbekistan and Kyrgyzstan: Study on Conditions for Sustainable Development; Occasional Paper No. 32; University of London: London, UK, 2000.

30. Alymbaeva, A. Institutional Development of Water Users Associations in Kyrgyzstan. Master's Thesis, Rochester Institute of Technology, New York, NY, USA, 2004.

31. Law on Unions (Associations) of Water Users. Available online: http://www.cawater-info.net/library/eng/ kyrgyz_wua_2002.pdf (accessed on 10 September 2016).

32. FAO National Gender Profile of Agricultural and Rural Livelihoods-Kyrgyz Republic. Country Gender Assessment Series. Available online: http:/ / www.fao.org/3/a-i5763e.pdf (accessed on 29 October 2017).

33. ADB Kyrgyz Republic: Developing Water Resources Sector Strategies in Central and West Asia. Technical Assistance Consultant's Report. Available online: https://www.adb.org/sites/default/files/projectdocument/79760/45353-001-tacr-01.pdf (accessed on 29 October 2017).

34. FAO Country Profile: Kyrgyzstan: Aquastat Survey. Available online: http://www.fao.org/nr/water/ aquastat/countries_regions/KGZ/index.stm (accessed on 29 October 2017).

35. The World Bank Group. Vulnerability, Risk Reduction and Adaptation to Climate Change: Kyrgyz Republic; The World Bank Group: Washington, DC, USA, 2011. Available online: http://sdwebx.worldbank.org/ climateportalb/doc/GFDRRCountryProfiles/wb_gfdrr_climate_change_country_profile_for_KGZ.pdf (accessed on 27 November 2017).

36. Population and Housing Census of the Kyrgyz Republic. National Statistics Committee of the Kyrgyz Republic. Available online: https://unstats.un.org/unsd/demographic/sources/census/wphc/Kyrgyzstan/ A5-2PopulationAndHousingCensusOfTheKyrgyzRepublicOf2009.pdf (accessed on 29 October 2017). 
37. Sultanov, T. Kyrgyzstan: Extended Migration Profile 2010-2015; National Institute for Strategic Studies of the Kyrgyz Republic. International Organization for Migration: Geneva, Switzerland, 2016.

38. Ritche, J.; Lewis, J.; Nicholls, C.; Ormston, R. Qualitative Research Practice: A Guide for Social Science Students and Researchers, 2nd ed.; 978-1446209127; Sage Publications: London, UK, 2014.

39. Liamputtong, P. Performing Qualitative Cross-Cultural Research; 978-0521898683; Cambridge University: New York, NY, USA, 2010.

40. The World Bank Data Kyrgyz Republic Data. Available online: https://data.worldbank.org/country/ kyrgyz-republic (accessed on 29 October 2017).

41. Ibraeva, G.; Moldosheva, A.; Niyazova, A. Kyrgyz country case study: Gender equality and development. In World Development Report 2012: Gender Equality and Development; World Bank Publication: Washington, DC, USA, 2011.

42. Parpart, J. Who is the 'other'? A postmodern feminist critique of women and development theory and practice. Dev. Chang. 1993, 24, 439-464. [CrossRef]

43. Parpart, J. Post-modernism, gender and development. In Power of Development; Crush, J., Ed.; Routledge: London, UK; New York, NY, USA, 1995.

(C) 2017 by the authors. Licensee MDPI, Basel, Switzerland. This article is an open access article distributed under the terms and conditions of the Creative Commons Attribution (CC BY) license (http://creativecommons.org/licenses/by/4.0/). 